not to adrocate this above any other locality, but to rnake known the existence, about 10 miles from the town of Harrismith, of what is a considerable rarity upon the high veldt-a large and comfortable farmhouse where paying guests are welcome. Of this house and its hospitality I had in the early part of last year two months' personal and happy experience ; and 1 have lately heard tbat the host and his wife, both loyal English Afrikanders, have survived the dangers and hardships of the war and are once more in a position to do their best for a limited number of visitors. It would give me pleasure to impart to anyone, medical or lay, all that I know about this house and its surroundings. I am, Sirs, yours faithfully,

W. LEE DICKINSON.

9. Chesterfield-street, Mayfair, W., Oct. 12th, 1900.

\section{THE CAUSATION OF SCURVY.}

\section{To the Editors of THE LANCE'T.}

SIRS,-Being much interested in scurvy I read with great expectation the article by Dr. Vaughan Harley and Mr. F. G. Jackson in THE LANCET of April 28th, 1900, p. 1184, and that by Staff Surgeon W. E. Home, R.N., in THE LANCET of August 4th, p. 321, and I regret to say that I an disappointed, for the following reasons.

Dr. Harley, as the result of feeding monkeys with bad meat, came to the conclusion that scurvy is caused by some poison in tainted (flesh) food. Now this may or may not be correct, but it auite fails to account for the disease in men who only eat good grain stuffs. I have seen a good deal of scurvy amongst non-meat-eating Indian troops both on service and in peace time, and have always found it to be caused solely by a diet containing too little fresh vegetables or fruits. I am of opinion that the disease was so caused as it was always cured by the addition to the diet of fresh potatoes, or dates, or limes, without any change being made in the food and water the patients were originally taking, without change of locality or circum stances, and without drugs. I am unable to give an opinion as to the prophylactic or curative powers of tinned milk, of pressed vegetables, of onions, of preserved limejuice, of fresh meat, or of fresh milk, though a recent experience of mine seemed to show that those men who could afford to buy milk were not attacked, while others under exactly the same conditions, but without milk, were attacked, and as regards fresh meat Nansen has proved that a diet of that alone is quite sufficient.

Staff-Surgeon Home suggests that scurvy is "an infection of the mouth with micro-organisms out of decayed food." I do not think that this is so, as in large outbreaks I have seen amongst non-meat-eating men, the various grains which formed the food staples were excellent, and the affection of the gums was not the first symptom observed. Also the gums are not in a state of inflammation-gingivitis. At a certain stage of the disease-generally early, very occasionally late, and $I$ have read sometirnes not at all-they become swelled by the scorbutic fibrinous infiltration (except places where teeth are absent), and any ulceration which may supervene later is quite unspecific. "With reference to the "orthodox view" given by Staff Surgeon Home let me give a typical case. A healthy sepoy, living in cantonments, wishes to save money. He has to pay for and eat the flour, rice, or dhal cooked by his company cook, so he saves by depriving himself of extras such as milk and vegetables, and meat if a meat eater. In two or three months that man will be in hospital with scurvy, and in a fairly short time he will, by the simple addition of fresh limes or potatoes to bis original diet, be quite fit for duty. "Preceding hardships" are not required for the production of scurvy, and I think it a good working rule to fear that men will become scorbutic if they cannot get either green vegetables, or fruit, or fresh milk, or fresh meat. I am, Sirs, yours faithfully,

Grantown-on-Spey. C. B. Maitlayo, F.R.C.P. Edin. Lieutenant-Colonel I.M.S.

\section{“TWO CASES OF ARTERIO-VENOUS ANEURYSM." \\ To the Editors of THE LANCET.}

SIRS, - I am much interested in the two cases of arterio-venous aneurysm reported in THE LANCET of Oct. 13th, (p. 1073) by Lieutenant-Colonel J. T. Lewtas, I.M.S. The result of the first case, treated by ligature of the vein by means of two ligatures applied one above and one below the opening into it and by ligature of the artery above the opening into it, is eminently satisfactory, for the disease was cured and the limb was saved, The result of the second case is, I should consider, eminently unsatisfactory, for the limb was amputated I have on one occasion tied the artery above the opening into it for the cure of arterio-venous aneurysm of the popliteal artery and vein with the same unfortunate result as that following Colonel Lewtas's operation and it is curious how frequently gangrene has followed this procedure. Gan. grene is much more common in cases of femoral arterio venous aneurysm after ligature of the artery by a single ligature applied to the vessel above the opening into it than when a ligature is applied above the aneurysm for the cure of popliteal aneurysm (Hunter"s operation). I do not know that this is to be wondered at, but it is certainly true. On the other hand, tying both artery and vein above and below the opening into them and dissecting out the sac bas been attended by most satisfactory results. This is undoubtedly a severe and sometimes a difficult operation, but it can usually be performed. In one case reported by Dr. Keen where the common carotid and the jugular veins were involved it was found impossible to dissect out the sac, but even this case was cured.-I am, Sirs, yours faithfully,

FREDERTCK PAGS,

Proffssor of Surgery, Durham Unirersity.

Newcastle-upon-Tyne, Dct. 15th, 19:0.

\section{"THE LONDON AND COUNTIES MEDICAL PROTECTION SOCIETY AND THE GENERAL MEDICAL COUNCIL:"}

\section{To the Editors of THE LANCET.}

Sins, - In reply to MIr. T. Bryant's letter, dated May 5th, pub!ished in THE LA NCET of Oet. 13th (p. 1097), I beg leave to say that I still regard as accurate the statement contained in the seconci paragraph of that letter. The paragraph is printed between inverted commas and is quoted from the last annual report of my society. I know no reason why anyone should accept as convincing Mr. Bryant's expression of his perso:al opinion concerning the cases to which he refers; and I see nothing more in his letter than a mere expression of his personal opinion. I am, Sirs, yours faithfully,

\section{Oct. 15th, 1300. HUGH WOODS, Honorary General Secretary.}

\section{"THE SMOKE NUISANCE."}

To the Editors of THE LANCET.

SiRs,-In answer to the letter from Mr. F. W. Alexander on the above subject which appeared in THE L $\Lambda$ NCET of Oct. 13th, (p. 1098) I should like to point out that the coal Smoke Abatement Society is well aware that it or any individual may prosecute in a case of smoke nuisance, but that having considered the matter in all its bearings the committee of the society has determined, at any rate for the present, not to institute proceedings itself. The principal difficulty in the society instituting proceedings is that the society would have to prove in court a nuisance by the smoke, a not always easy thing to prove to the satisfaction of a magistrate, whereas if the vestry prosecutes it only has to prove that black smoke was ernitted, which under Section 23 and 24 constitutes a nuisance. Where there are public authorities constituted for the purpose of suppressing these nuisances my committee considered that it would be unwise of them to commence legal proceedings in cases which now number some thousands. - I am, Sirs, yours faithfully,

$$
\text { H. A. DES TCEXX. }
$$

Oct. 17th, 1900. Hon. Treasurer, Coai Smoke Abatement Saciety.

\section{NOTES FROM INDIA.}

\section{(From our SPECIAI CORRESPONDENT.)}

The Medical Staff for the China Expeditionary Foree.The Hospital Ship Gwalior-Beri-beri on H.M.S. Sphinx.-The Pasteur Institute at Kasauti.-Frthers Increase of Plague in India.

ONE hundred and thirty medical officers (all bnt eight of whom belong to the Indian Medical Service) having been detailed for duty with the China Expeditionary Force there 